\title{
GENOTYPIC AND PHENOTYPIC CORRELATION COEFFICIENT STUDIES FOR TARO (COLOCASIA ESCULENTA (L.) SCHOTT.)
}

\author{
KK PAUL*, MA Bari, SMS IsLam AND SC DEBNATH \\ Institute of Biological Sciences, Rajshahi University, Rajshahi-6205, Bangladesh
}

Key words: Colocasia esculenta, Genotypic, Phenotypic, Correlation

\begin{abstract}
Genotypic and phenotypic correlation coefficient of taro, (Colocasia esculenta (L.) Schott.) were estimated for 19 characters. Leaf length, leaf number, LAI, cormel length, corm weight, cormel weight, cormel length showed significant and positive correlation with yield per plant in both genotypic and phenotypic levels.
\end{abstract}

In Bangladesh edible aroid, taro (locally called mukhikachu) is an ancient crop growing on hilly areas as well as in plain lands with diverse structures and characteristics. Taro belongs to the genus Colocasia, of the family Araceae. It is one of the oldest crops said to have originated in India or southeast Asia (Ramanath Rao 2000). There are at least two botanical varieties. Of the two taro, Colocasia esculenta (L.) Schott var. antiquorum (Schott.) which is synonymous with $C$. esculenta var. globulifera Engl. \& Krause plays a significant role in tuber crops (Purseglove 1972). According to Perseglove (1979), the main difference between the typical esculenta and antiquorum is the length of the sterile appendix of the spadix. The sterile tip of antiquorum is usually much longer in comparison with the one of esculenta. Taro (Colocasia esculenta (L.) Schott.) ranks 14 among the staple/vegetable crops worldwide. It can be used as food (for animals and human beings), medicinal, ornamental and industrial purposes. The whole part of this plant (corm, cormels, stalk, inflorescence and flowers) can be used as food. Coursey (1968) gave the appropriate composition of corms as water 63 - 85 per cent, protein 1.3- 4.0 per cent, fat.2.0 -.4.0 per cent, carbohydrate 13 - 29 per cent, fibre $0.6-1.2$ per cent, ash $0.6-1.3$ per cent, vitamin $B$ and $\mathrm{C}$ are also present in appreciable quantities. In recent years yields of taro have increased dramatically through breeding and selection (Wilson 1985). On this perspective, the present research was undertaken to make a scientific evaluation of the taro growing in the country covering the aspects of biometrical characterization. Thus the present investigation was designed to estimate the nature and magnitude of relationships (genotypic and phenotypic) between yield and yield components for identification of best genotypes of taro.

Four hundred and fifty seven edible taro, C. esculenta germplasm accessions were collected from aroid growing 13 districts of Bangladesh in 2005 - 2006. Collected propagules were maintained during the on set of rainy season at the experimental farm of the Institute of Biological Sciences, Rajshahi University, Bangladesh 2005 - 2008. Selected 30 elite genotypes were sown on March, 2006. All recommended agricultural practices were followed during cultivation period.

The experiment was set up in a RCB design with three replications. In each experimental plot, plant propagules are planted with row to row spacing $0.60 \mathrm{~m}$ and plant to plant spacing $0.45 \mathrm{~cm}$. was maintained.

When the vegetative growth is in climax, leaves become yellowish, dry and dropping then the quantitative parameters such as plant height, petiole length, petiole breadth, leaf length, leaf breadth, leaf number, leaf area Index, inflorescence length, peduncle length, spathe length, spathe

*Author for correspondence: <krshnnd@yahoo.com>. 
breadth, corm length, corm breadth, cormel length, cormel breadth, cormel number, cormel weight, corm weight and yield per plant were observed and data were recorded following the descriptors of Taro with necessary modifications (IPGRI 1999). Leaf area index (LAI) was calculated as leaf length $\times$ leaf breadth $\times 0.75$ (Montgomery 1911).

The collected data were analyzed following the biometrical techniques of analysis developed by Mather (1949) based on mathematical model of Fisher et al (1932) using the SPSS and excel software. Analysis of variances and the components of variances viz., Genotypic variance $\left(\sigma_{\mathrm{g}}^{2}\right)$, phenotypic variance $\left(\sigma_{p}^{2}\right)$, and environment variance $\left(\sigma_{e}^{2}\right)$ and covariance were estimated following the methods as described by Singh and Chaudhary (1977).

Correlation coefficients between all possible pairs of characters both at phenotypic $\left(r_{p}\right)$ and genotypic $\left(\mathrm{r}_{\mathrm{g}}\right)$ coefficients were computed and presented in Tables 1 and 2, respectively.

In genotypic level, only positive and highly significant association was found with spathe breadth. Petiole length showed highly significant and positive correlation effect with spathe breadth. Only significant and positive association was found with spathe breadth. Highly significant and positive association was found with spathe breadth and yield per plant. Inflorescence length exhibited positive and highly significant association was found with spathe breadth and yield per plant. Spathe length exhibited significant and positive correlation with cormel breadth and corm weight. Spathe breadth exhibited highly significant and positive association with corm breadth, corm weight, cormel number, cormel weight, cormel length, cormel breadth and yield per plant. Cormel length showed significant and positive correlation with yield per plant. Cormel breadth showed significant and positive association with yield per plant.

At phenotypic levels, plant height exhibited highly significant and positive correlation with petiole length, petiole breadth, leaf length, leaf breadth, leaf number, leaf area index, inflorescence length, peduncle length, spathe length, spathe breadth, corm length, corm weight and cormel breadth. Petiole length showed highly significant and positive association in phenotypic level with petiole breadth, leaf length, leaf breadth, leaf number, leaf area index, inflorescence length, spathe length, spathe breadth, corm length, corm weight, cormel weight, cormel length and cormel breadth. Leaf area index showed very highly significant and positive correlation with inflorescence length, peduncle length, spathe breadth, corm length, corm breadth, corm weight, cormel number, cormel weight, cormel breadth and yield per plant. Corm length showed highly significant and positive association with corm breadth, corm weight, cormel number, cormel weight, cormel length, cormel breadth and yield per plant. Corm breadth also exhibited strong and highly positive association with corm weight, cormel number, cormel weight, cormel length, cormel breadth and yield per plant. Corm weight showed significant and positive association with cormel number, cormel weight, cormel length, cormel breadth and yield per plant. Works of some researchers found relationship with our results are discussed here. Mahonkumar et al. (1990) reported that the characters, mean weight of cormels/ plant, number of cormels/plant and LAI were positively and significantly correlated with yield. Pandey et al. (1996) assessed correlation for 31 genotypes of taro with 8 yield contributed characters and they observed that yield per plant was significantly and positively correlated with most of characters (leaf length, leaf width, suckers/plant, weight of mother cormels, cormels/plant, weight of cormels and yield per plant) at both phenotypic and genotypic levels. Dwivedi and Sen (1999) studied 30 genotypes of taro for correlation and observed that cormel yield had positive and significant association with the length and girth of main sucker, number of cormels per plant and corm weight but it was negatively correlated with corm/cormel ratio. Velayudhan et al. (2000) found that cormel number, cormel thickness, plant height, leaf length and leaf width had higher positive correlation with cormel yield. Cheema et al. (2007) studied in arvi total yield per plant was positively and significantly correlated with number of corms and cormels per plant and corm length. Paul et al. (2011) found 


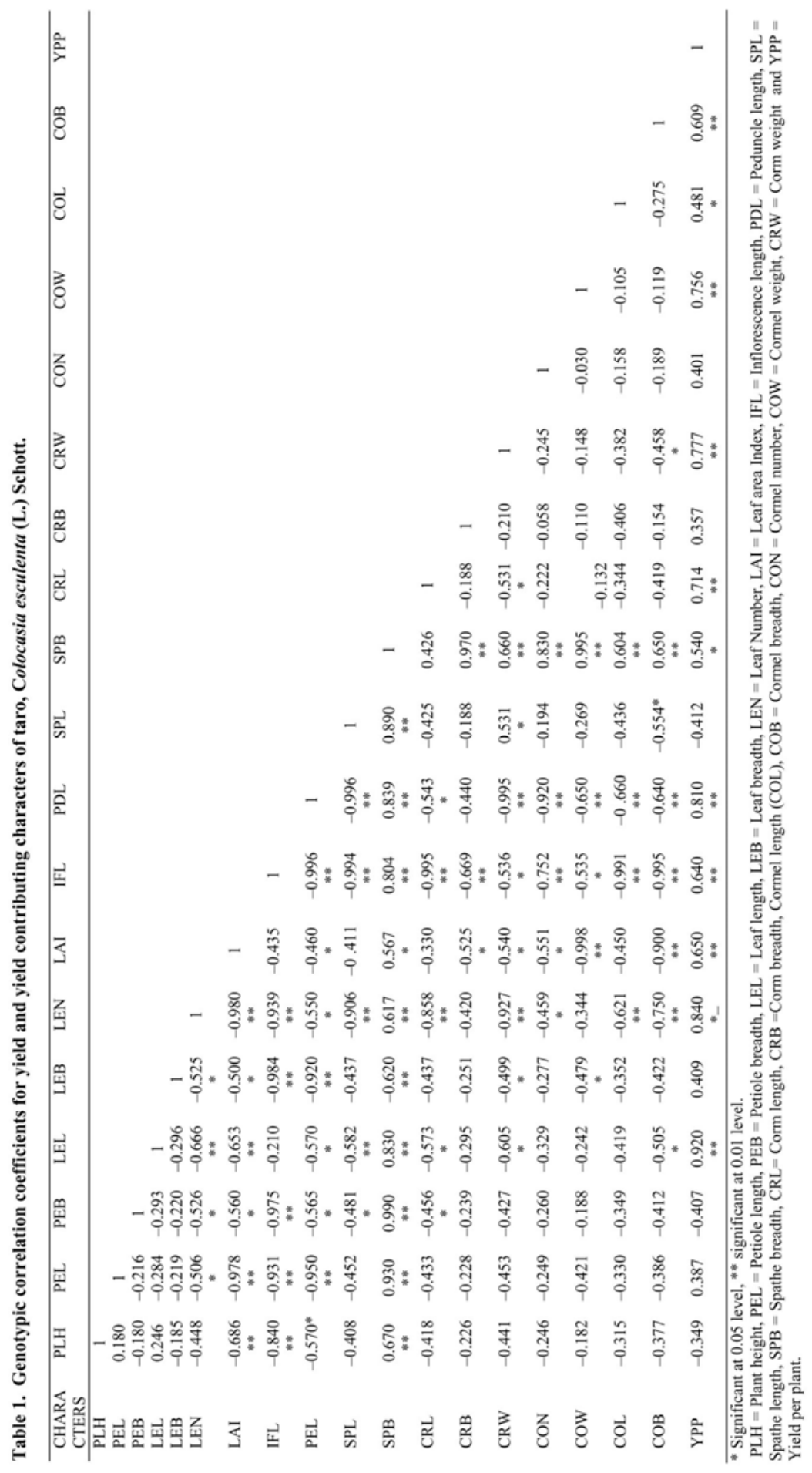




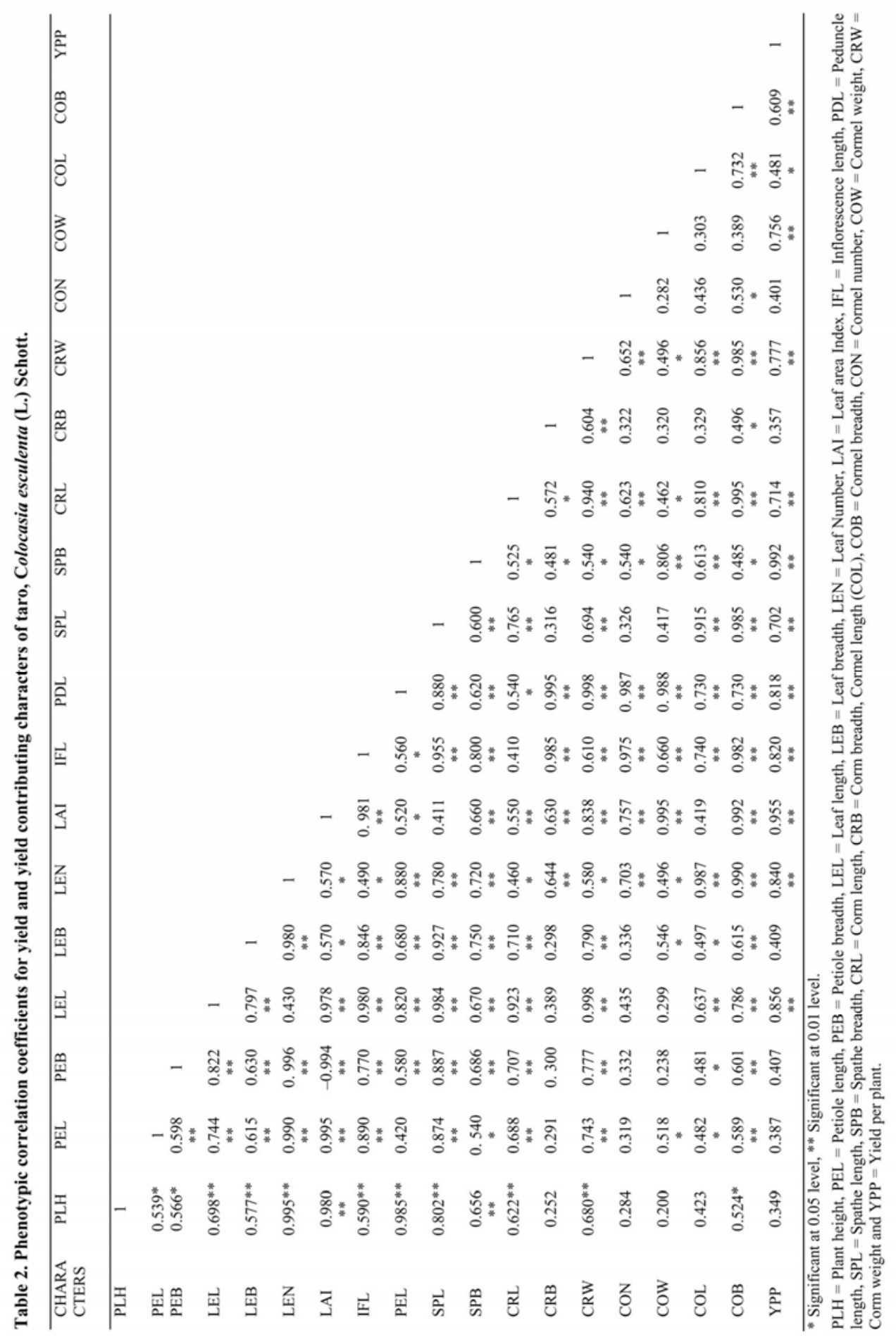


that the yield per plant showed significant and positive phenotypic correlation with petiole length, leaf length, leaf breadth, leaf number, inflorescence length, spathe length and spathe breadth and significant correlation with plant height and leaf number in aqua aroids (taro) at genotypic level.

\section{References}

Cheema DS, Singh H, Dhatt A S and Gang N 2007. Studies on gentic variability and correlation for yield and quality traits in Arvi (Colocasia esculenta Schott.). 752.

Coursey DG 1968. The edible aroids. World Crops. 20(4): 25-30.

Dwivedi AK and Sen H 1999. Correlation and path coefficient studies in taro (Colocasia esculenta var.antiquorum). J. Root Crops. 25(1): 51-54.

Fisher RA, Immer RR and Tedin O 1932. The genetic interpretation of statistics on the third degree in the inheritance of quantitative inheritance. Genetics 17: 107-124.

IBPGRI 1999. Descriptors for taro (Colocasia esculenta). IPGRI, Rome, Italy.

Mather K 1949. Biometrical genetics, Dover publication. Inc. New York.

Montgomery EG 1911.Correlation studies in corm. Nebr. Agr. Exp. Sta. Ann.Rep. 24: 108-159

Mohonkumar CR, Sarawathy P and Sadanandan N 1990. Correlation and path coefficient analysis on yield and yield component in Taro. J Root Crops 16(2): 140 -141.

Pandey G, Dhobal VK and Sapra RL.1996. Genetic variability, correlation and path analysis in Taro. (Colocasia esculenta). J. Hill. Res. (India) 9(2): 299-302.

Paul KK, Bari MA and Debnath SC 2011.Correlation and path coefficient studies for plat characters in Aqua aroids, Colocasia esculenta (L.) Schott. J. Sci. Res. 3(1):169-176.

Purseglove JW 1972. Tropical crops, Monocotyledons 1. Longman, London, 62-69.

Pursegove JW1979. Tropical crops-Monocotyledons, Longman,London.

Ramanath Rao V 2000.Taro genetic diversity and its use in taro improvement: Potential Root crops for foodand industrial resources, Twelfth Symposium of the International Society for tropical Root crops(ISTRC). Makoto Nakatani and Katsumi Komaki (eds). p. 561.

Singh RK and Chaudhary BD 1977. Biometrical methods in quantitative genetic analysis. Kalnani publishers, New Delhi, India. pp. 39-68.

Velayudhan KC, Leji RS and Rajlakshmy C 2000. Correlation and path analysis in Taro (Colocasia esculenta (L.) Schott.) morphotypes. J. Root Crops 26(2): 36-39.

Wilson JE 1985. Root Crops. IRETA Annual Research Report. pp. 29-38.

(Manuscript received on 21 November, 2012; revised on 10 October, 2013) 